Powell Phillips (Cardiff), Dr. J. F. Warin (Oxford), Dr. R. C. Wofinden (Bristol). The study in these eight areas was co-ordinated by Dr. C. L. Miller and Mrs. A. Allchin (Central Public Health Laboratory, Colindale).

We are also grateful to the members of the M.R.C. Measles Vaccines Committee for helpful comments on the draft of this report.

\section{References}

Bartlett, M. S. (1960). Fournal of the Royal Statistical Society, A, 123, 37 Benjamin, B., and Gore, A. T. (1952). British fournal of Social Medicine, 6, 197.

British Medical fournal, 1969, 1, 791

Hedrich, A. W. (1933). American Fournal of Hygiene, 17, 613.

Hope Simpson, R. E. (1948). Lancet, 2, 755.

M.R.C. Measles Vaccines Committee (1971). Practitioner. In press.

Parry, W. H. and Ducksbury, C.F.J. (1970). Medical Officer, 124, 329

Report (1968). On the State of the Public Health. London, H.M.S.O

Report (1969). On the State of the Public Health. London, H.M.S.O

Stocks, P., and Karn, M. (1928). Annals of Eugenics, 3, 361.

\title{
Uterine Hypertonus during Labour Induced by Prostaglandins
}

\author{
G. ROBERTS, A. C. TURNBULL
}

British Medical fournal, 1971, 1, 702-705

\section{Summary}

Labour was induced successfully at or near term in 34 out of 35 cases by combined amniotomy and intravenous infusion of either prostaglandins $F_{2} \alpha, E_{2}$, or $E_{1}$. Of particular importance is the finding of hypertonus in 4 of the 18 cases induced with prostaglandin $\mathbf{E}_{2}$.

\section{Introduction}

Prostaglandins, a group of specialized hydroxy-fatty acids, have been shown to possess spasmogenic effects on human non-pregnant (Pickles et al., 1965) and pregnant myometrium (Embrey and Morrison, 1968). Bygdeman et al. (1968) showed that the $\mathrm{E}$ prostaglandins caused "unphysiological elevation of tonus" and thought that they were unsuitable for the induction of labour. More recently, however, they have been used successfully to induce labour at or near term, without hypertonus (Embrey, 1970; Karim et al., 1970). As relatively few centres are investigating the clinical applications of prostaglandin administration, the experience in Cardiff is presented of the intravenous infusion of prostaglandins $F_{2} \alpha, E_{2}$, and $E_{1}$ for induction of labour, with particular emphasis on the incidence of uterine hypertonus during administration of prostaglandin $\mathrm{E}_{2}$.

\section{Patients and Methods}

Patients chosen for study were those in whom induction of labour was required because of the obstetric conditions shown in the Table. The state of the cervix was assessed and classified according to the criteria of Embrey and Anselmo (1962). After amniotomy the uterine activity was recorded by measuring intra-amniotic pressure changes by means of an open-ended saline-filled catheter inserted into the uterus with the aid of a modified Drew Smythe catheter. The fluid-filled catheter was then connected to a Sanborn 267 AC pressure

\footnotetext{
Department of Obstetrics and Gynaecolosy, Welsh National School of Medicine, Cardiff CF2 1XF

G. ROBERTS, M.B., M.R.C.O.G., Senior Registrar (Present address: St. David's Hospital, Cardiff CF1 9TZ)

A. C. TURNBULL, M.D., F.R.C.o.G., Professor
}

transducer and the tracings were recorded by means of a Hewlett-Packard 7712 amplifier and recorder.

Spontaneous uterine activity was observed for one hour before the intravenous infusion of sterile solutions of either prostaglandins $\mathrm{F}_{2} \alpha, \mathrm{E}_{2}$, or $\mathrm{E}_{1}$. Patients showing strong stimulatory uterine effects after amniotomy alone were excluded from the study. The prostaglandins, which had been previously diluted in ethanol $(0.5 \mathrm{mg} / \mathrm{ml})$ and stored at $-20^{\circ} \mathrm{C}$, were further diluted with iso-osmotic saline before being administered by means of a Palmer continuous 'slow injector. The maternal pulse rate, blood pressure, and fetal heart rates were recorded frequently.

For prostaglandin $F_{2} \alpha$ an infusion rate of $3 \mu \mathrm{g} / \mathrm{min}$ was used initially and doubled when necessary to obtain optimum uterine activity. In the earlier cases induced with prostaglandin $E_{2}$ an initial infusion rate of $3 \mu \mathrm{g} / \mathrm{min}$ was also used, but with experience smaller doses were often found to be effective $(0.75-1.5 \mu \mathrm{g} / \mathrm{min})$. At first the infusions were usually continued until the patient delivered, but as the study progressed it was found that the infusion could be discontinued when labour was well established. The type of prostaglandin used in each individual was determined by its availability at the time rather than by random selection. Prostaglandin $F_{2} \alpha$ was used in seven patients, $E_{2}$ in 18 , and $E_{1}$ in 10.

In the group studied (see Table) 11 were primigravid patients and 13 were of parity 3 or greater. The physical state of the cervix was noted to be unfavourable in 10 cases intermediate in 19, and favourable in 6.

A constant feature of our intravenous infusion of prostaglandins has been the development of a "red line" over the course of the vein from the site of the cannula, and some patients have complained of severe pain in the forearm or shoulder on the same side as the infusion but distant from the cannula in the vein.

\section{Results}

Induction of labour was successful in 34 out of 35 cases; all patients successfully induced delivered within $13 \frac{1}{2}$ hours. The latent period between the start of the infusion and the onset of stimulated uterine activity ranged from 20 to 40 minutes with prostaglandin $\mathrm{F}_{2} \alpha$, but with the $\mathrm{E}$ prostaglandins the latent period was much shorter, about 10 minutes on average. In agreement with the findings of other workers, $E$ prostaglandins were found to be more potent oxytocics than $F_{2} \alpha$, and the $\mathrm{E}$ compounds could effectively induce labour in smaller doses than prostaglandin $F_{2} \alpha$. 
Details of Cases

\begin{tabular}{|c|c|c|c|c|c|c|c|c|c|c|c|c|}
\hline \multirow{3}{*}{$\begin{array}{l}\text { Case } \\
\text { No. } \\
1\end{array}$} & \multirow{3}{*}{$\frac{\text { Age }}{24}$} & \multirow{3}{*}{ Gravida } & \multirow{3}{*}{ Maturity } & \multirow{4}{*}{\begin{tabular}{|c}
$\begin{array}{c}\text { Indication for } \\
\text { Induction }\end{array}$ \\
$\begin{array}{c}\text { Rhesus iso- } \\
\text { immunization } \\
\text { Pre-eclampsia }\end{array}$
\end{tabular}} & \multirow{4}{*}{\begin{tabular}{c}
\multicolumn{1}{c}{$\begin{array}{c}\text { State of } \\
\text { Cervix }\end{array}$} \\
Intermediate \\
Unfavourable
\end{tabular}} & \multirow[b]{2}{*}{ Prostaglandin } & \multicolumn{3}{|c|}{ Infusion Time } & \multicolumn{2}{|c|}{$\begin{array}{l}\text { Induction-delivery } \\
\text { Time from A.R.M. }\end{array}$} & \multirow[b]{2}{*}{ Delivery } \\
\hline & & & & & & & \multirow{3}{*}{\begin{tabular}{|c|}
$\begin{array}{c}\text { Rate } \\
(\mu \mathrm{g} / \mathrm{min} .)\end{array}$ \\
3 \\
6 \\
3 \\
6
\end{tabular}} & \multicolumn{2}{|c|}{$\begin{array}{c}\text { Time } \\
\mathrm{hr} \quad \min \end{array}$} & & $\min$ & \\
\hline & & & & & & $\mathrm{F}_{2} \alpha \quad\{$ & & $\begin{array}{l}7 \\
2\end{array}$ & $\overline{45}$ & 10 & 45 & Normal \\
\hline 2 & 22 & 1 & 39 & & & $\mathrm{~F}_{2} \alpha$ & & $\begin{array}{l}2 \\
3 \\
6\end{array}$ & $\frac{35}{25}$ & 12 & - & Normal \\
\hline $\begin{array}{l}3 \\
4 \\
5 \\
6\end{array}$ & $\begin{array}{l}22 \\
24 \\
18 \\
39\end{array}$ & $\begin{array}{l}3 \\
1 \\
2 \\
1\end{array}$ & $\begin{array}{l}43 \\
40 \\
39 \\
38\end{array}$ & $\begin{array}{l}\text { Postmaturity } \\
\text { Pre-eclampsia } \\
\text { Pre-eclampsia } \\
\text { Pre-eclampsia }\end{array}$ & $\begin{array}{c}\text { Favourable } \\
\text { "’ } \\
\text { Unfavourable }\end{array}$ & $\begin{array}{l}F_{2} \alpha \\
F_{2} \alpha \\
F_{2} \alpha \\
F_{2} \alpha\end{array}$ & $\begin{array}{l}0 \\
3 \\
3 \\
3 \\
3 \\
6\end{array}$ & $\begin{array}{l}7 \\
7 \\
6 \\
2 \\
1 \\
0\end{array}$ & $\begin{array}{r}50 \\
30 \\
5 \\
30 \\
\end{array}$ & $\begin{array}{r}8 \\
7 \\
4 \\
13\end{array}$ & $\begin{array}{l}50 \\
\frac{30}{30}\end{array}$ & $\begin{array}{l}\text { Normal } \\
\text { Normal } \\
\text { Normal } \\
\text { L.S.C.S. at full dilatation }\end{array}$ \\
\hline 7 & 22 & 1 & Uncertain & Placental insufficiency & " & $\mathrm{F}_{2} \alpha$ & $\begin{array}{l}6 \\
3 \\
6\end{array}$ & $\begin{array}{r}9 \\
12 \\
6\end{array}$ & $\bar{z}$ & 33 & - & $\begin{array}{l}\text { Normal (syntocinon used } \\
\text { from 2-cm dilatation) }\end{array}$ \\
\hline $\begin{array}{r}8 \\
9 \\
10 \\
11\end{array}$ & $\begin{array}{l}35 \\
34 \\
19 \\
23\end{array}$ & $\begin{array}{l}1 \\
5 \\
2 \\
2\end{array}$ & \begin{tabular}{c|}
40 \\
38 \\
Uncertain \\
38
\end{tabular} & $\begin{array}{c}\text { Elderly primigravida } \\
\text { Pre-eclampsia } \\
\text { Pre-eclampsia } \\
\text { Rhesus iso- } \\
\text { immunization }\end{array}$ & $\begin{array}{c}\text { Intermediate } \\
\text { ", } \\
\text { Unfavourable }\end{array}$ & $\begin{array}{l}E_{2} \\
E_{2} \\
E_{2}^{2} \\
E_{2}\end{array}$ & $\begin{array}{l}3 \\
3 \\
3 \\
3\end{array}$ & $\begin{array}{l}3 \\
3 \\
3 \\
6\end{array}$ & $\bar{z}$ & $\begin{array}{r}7 \\
6 \\
10 \\
9\end{array}$ & $\frac{35}{40}$ & $\begin{array}{l}\text { Normal* } \\
\text { Normal } \\
\text { Normal } \\
\text { Normal }\end{array}$ \\
\hline $\begin{array}{l}12 \\
13\end{array}$ & $\begin{array}{l}33 \\
26\end{array}$ & $\begin{array}{l}3 \\
2\end{array}$ & $\begin{array}{l}43 \\
40\end{array}$ & $\begin{array}{l}\text { Postmaturity } \\
\text { Previous S.B. }\end{array}$ & $\begin{array}{c}\text { Intermediate } \\
,\end{array}$ & $\begin{array}{l}\mathrm{E}_{2} \\
\mathrm{E}_{2}\end{array}$ & $\begin{array}{l}1.5 \\
1.5 \\
0.75\end{array}$ & $\begin{array}{l}3 \\
3\end{array}$ & $\overline{10}$ & $\begin{array}{l}6 \\
5\end{array}$ & $\overline{20}$ & $\begin{array}{l}\text { Normal } \\
\text { Normal* }\end{array}$ \\
\hline $\begin{array}{l}14 \\
15\end{array}$ & $\begin{array}{l}30 \\
34\end{array}$ & $\begin{array}{l}4 \\
5\end{array}$ & $\begin{array}{l}42 \\
38\end{array}$ & $\begin{array}{c}\text { Postmaturity } \\
\text { Essential hypertension }\end{array}$ & Unfavourable & $\begin{array}{l}\mathrm{E}_{2} \\
\mathrm{E}_{2}\end{array}$ & $\begin{array}{l}1.5 \\
1.5 \\
3\end{array}$ & $\begin{array}{l}2 \\
3 \\
1\end{array}$ & $\begin{array}{l}\overline{10} \\
50\end{array}$ & $\begin{array}{l}6 \\
6\end{array}$ & $\overline{17}$ & $\begin{array}{l}\text { Normal } \\
\text { Normal }\end{array}$ \\
\hline $\begin{array}{l}16 \\
17\end{array}$ & $\begin{array}{l}24 \\
29\end{array}$ & $\begin{array}{l}1 \\
1\end{array}$ & $\begin{array}{l}40 \\
40\end{array}$ & $\begin{array}{l}\text { Pre-eclampsia } \\
\text { Pre-eclampsia }\end{array}$ & $\begin{array}{l}\text { Favourable } \\
\text { Unfavourable }\end{array}$ & $\begin{array}{l}E_{2} \\
E_{2}\end{array}$ & $\begin{array}{l}3 \\
1.5 \\
1.5 \\
0.75\end{array}$ & $\begin{array}{l}1 \\
1 \\
3 \\
8\end{array}$ & $\begin{array}{r}50 \\
50 \\
45 \\
5\end{array}$ & $\begin{array}{r}5 \\
13\end{array}$ & $\begin{array}{l}20 \\
30\end{array}$ & $\begin{array}{l}\text { Normal } \\
\text { Forceps* }\end{array}$ \\
\hline 18 & 22 & 1 & 41 & Pre-eclampsia & Intermediate & $\mathrm{E}_{2}$ & $\begin{array}{l}0.75 \\
1.5\end{array}$ & $\begin{array}{l}0 \\
2 \\
2\end{array}$ & $\begin{array}{l}30 \\
20\end{array}$ & 7 & 45 & Forceps \\
\hline 19 & 22 & 2 & 42 & Postmaturity & Favourable & $\mathbf{E}_{2}$ & $\begin{array}{l}1.3 \\
0.75 \\
1.5\end{array}$ & 2 & $\begin{array}{r}20 \\
5 \\
45\end{array}$ & 4 & 50 & Normal \\
\hline 20 & 18 & 1 & 41 & Postmaturity & " & $\mathrm{E}_{2}$ & $\begin{array}{l}1.3 \\
0.75 \\
1.5\end{array}$ & $\begin{array}{l}1 \\
1 \\
6\end{array}$ & $\begin{array}{l}43 \\
11\end{array}$ & 10 & 20 & Normal* \\
\hline 21 & 22 & 3 & 37 & $\begin{array}{l}\text { Rhesus iso- } \\
\text { immunization }\end{array}$ & Intermediate & $\mathbf{E}_{2}$ & 0.75 & $\begin{array}{l}0 \\
3 \\
2\end{array}$ & 30 & 5 & 30 & Normal \\
\hline $\begin{array}{l}22 \\
23 \\
24\end{array}$ & $\begin{array}{l}29 \\
17 \\
22\end{array}$ & $\begin{array}{l}2 \\
1 \\
3\end{array}$ & $\begin{array}{l}40 \\
42 \\
41\end{array}$ & $\begin{array}{l}\text { Previous history } \\
\text { Postmaturity } \\
\text { Postmaturity }\end{array}$ & "' & $\begin{array}{l}E_{2} \\
E_{2} \\
E_{2}\end{array}$ & $\begin{array}{l}0.75 \\
0.75 \\
0.75 \\
1.5\end{array}$ & $\begin{array}{l}2 \\
3 \\
3 \\
6\end{array}$ & E & $\begin{array}{r}5 \\
7 \\
10\end{array}$ & $\frac{30}{-}$ & $\begin{array}{l}\text { Normal } \\
\text { Normal } \\
\text { Normal }\end{array}$ \\
\hline $\begin{array}{l}25 \\
26\end{array}$ & $\begin{array}{l}26 \\
27\end{array}$ & $\begin{array}{l}4 \\
4\end{array}$ & $\begin{array}{l}40 \\
38\end{array}$ & $\begin{array}{l}\text { Pre-eclampsia } \\
\text { Rhesus iso- } \\
\text { immunization }\end{array}$ & $\begin{array}{l}\text { Unfavourable } \\
\text { Intermediate }\end{array}$ & $\begin{array}{l}E_{2} \\
E_{1}\end{array}$ & $\begin{array}{l}1.3 \\
1.5 \\
1.5\end{array}$ & $\begin{array}{l}0 \\
4 \\
2\end{array}$ & $\begin{array}{l}\overline{45} \\
10\end{array}$ & $\begin{array}{l}5 \\
3\end{array}$ & $\begin{array}{l}45 \\
10\end{array}$ & $\begin{array}{l}\text { Normal } \\
\text { Normal }\end{array}$ \\
\hline $\begin{array}{l}27 \\
28 \\
29 \\
30 \\
31 \\
32 \\
33\end{array}$ & $\begin{array}{l}29 \\
31 \\
27 \\
31 \\
30 \\
17 \\
29\end{array}$ & $\begin{array}{l}3 \\
4 \\
2 \\
2 \\
2 \\
1 \\
2\end{array}$ & $\begin{array}{l}41 \\
41 \\
41 \\
41 \\
40 \\
38 \\
40\end{array}$ & $\begin{array}{l}\text { Postmaturity } \\
\text { Postmaturity } \\
\text { Postmaturity } \\
\text { Postmaturity } \\
\text { Pre-eclampsia } \\
\text { Pre-eclampsia } \\
\text { Antepartum } \\
\text { haemorrhage }\end{array}$ & $\begin{array}{c}\text { Favourable } \\
\text { Intermediate } \\
\text { ", } \\
\text { Unfavourable } \\
\text { Intermediate }\end{array}$ & $\begin{array}{l}E_{1} \\
E_{1} \\
E_{1} \\
E_{1} \\
E_{1} \\
E_{1} \\
E_{1}\end{array}$ & $\begin{array}{l}1.5 \\
1.5 \\
1.5 \\
1.5 \\
1.5 \\
1.5 \\
0.75 \\
1.5\end{array}$ & $\begin{array}{l}2 \\
2 \\
3 \\
3 \\
2 \\
7 \\
1 \\
2\end{array}$ & $\begin{array}{l}\overline{45} \\
45 \\
= \\
= \\
=\end{array}$ & $\begin{array}{l}3 \\
3 \\
4 \\
4 \\
4 \\
8 \\
6\end{array}$ & $\begin{array}{l}5 \\
45 \\
45 \\
15 \\
10 \\
\end{array}$ & $\begin{array}{l}\text { Normal } \\
\text { Normal } \\
\text { Normal } \\
\text { Normal } \\
\text { Normal } \\
\text { Normal } \\
\text { Normal }\end{array}$ \\
\hline $\begin{array}{l}34 \\
35\end{array}$ & $\begin{array}{l}20 \\
22\end{array}$ & $\frac{2}{3}$ & $\begin{array}{l}40 \\
38\end{array}$ & $\begin{array}{l}\text { Pre-eclampsia } \\
\text { Rhesus iso- } \\
\text { immunization }\end{array}$ & Unfavourable & $\begin{array}{l}\mathrm{E}_{1} \\
\mathrm{E}_{1}\end{array}$ & $\begin{array}{l}1.7 \\
0.75 \\
1.5 \\
3 \cdot 0\end{array}$ & $\begin{array}{l}2 \\
4 \\
4\end{array}$ & $\overline{30}$ & $\begin{array}{r}4 \\
13\end{array}$ & 二 & $\begin{array}{l}\text { Normal } \\
\text { Normal }\end{array}$ \\
\hline
\end{tabular}

A.R.M. = Artificial rupture of membranes. L.S.C.S. $=$ Lower segment caesarean section. ${ }^{*}$ Hypertonus occurred.

Of the 34 successful cases, 31 had spontaneous vaginal deliveries. Two patients required forceps deliveries for delay in the second stage of labour. In one patient (Case 6) a lower uterine segment caesarean section was considered desirable even at full dilatation of the cervix because she was a 39 . year-old primigravida and the fetal head remained in high cavity. The single failure in the series was Case 7. Her cerv: $x$ was only $2 \mathrm{~cm}$ dilated after infusion of prostaglandin $F_{2} \alpha$ for 18 hours; uterine activity was augmented by an oxytocin infusion as the prostaglandin supply had been exhausted. Two babies (from Cases 10 and 35) showed the respiratory distress syndrome, though both were of low birth weight. One patient (Case 9) had an atonic postpartum haemorrhage though this was her fifth pregnancy and there was a history of a similar haemorrhage in one of her previous pregnancies. Uterine hypertonus occurred in four cases during administratinn of prostaglandin $\mathbf{E}_{2}$.

Case 8.-This patient was an elderly primigravida in whom labour was induced at term. Owing to an error in adjusting the speed of the injector pump, an accidental overdose of prostaglandin $\mathrm{E}_{2}(18 \mu \mathrm{g} . / \mathrm{min})$ was administered. Three minutes after starting the infusion she complained of intense continuous abdominal pain. Hypertonus was suspected and the tracings confirmed the tetanic-like spasm of the uterus $(50 \mathrm{~mm} \mathrm{Hg}$ ) the effect lasting for eight minutes (Fig. 1). Immediately the hypertonus was recognized the infusion was stopped, and normal basal uterine tone (15 $\mathrm{mm} \mathrm{Hg}$ ) was restored within five minutes. During this time no abnormality of the fetal heart rate, maternal pulse, or blood pressure readings was noted. After an interval of 20 minutes the infusion was recommenced at a dose rate of $3 \mu \mathrm{g} / \mathrm{min}$; normal uterine contractility was observed and the patient was delivered normally of a healthy baby 7 hours 35 minutes after amniotomy.
Case 13.-A 26-year-old gravida-2 had labour induced at term. Prostaglandin $\mathrm{E}_{2}$ was infused $(1.5 \mu \mathrm{g} / \mathrm{min})$. Ten minutes later the basal uterine tone rose to $30-40 \mathrm{~mm} \mathrm{Hg}$ (Fig. 2) for a period of eight minutes. Within five minutes of stopping the infusion normal basal uterine activity $(15 \mathrm{~mm} \mathrm{Hg}$ ) was observed. The uterine hypertonus in this case was also recognized clinically.

Case 17.-Labour was induced in this patient at term because of pre-eclampsia. Successful induction was achieved at a dose rate of $1.5 \mu \mathrm{g} / \mathrm{min}$; normal labour contractions were observed until 225 minutes of prostaglandin administration (Fig. 3), when hyper-

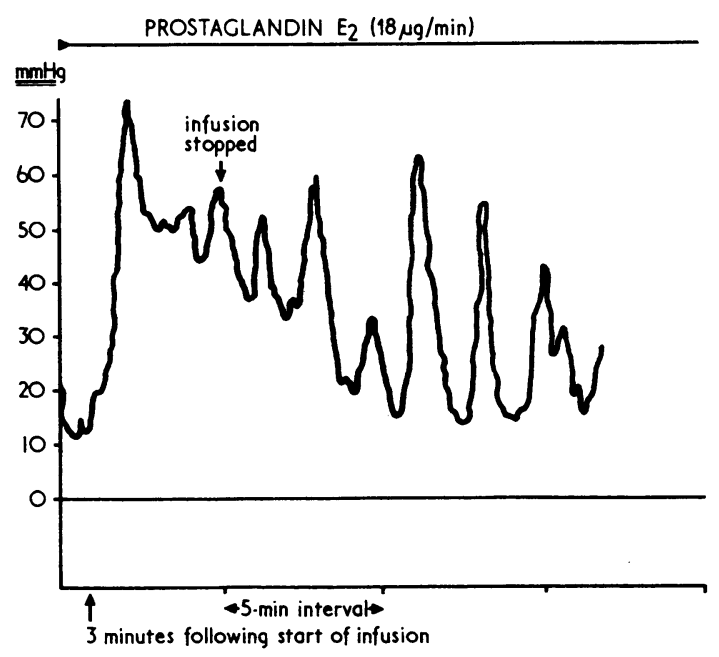

FIG. 1-Case 8. Hypertonus due to overdosage of prostaglandin $\mathrm{E}_{2}$. 


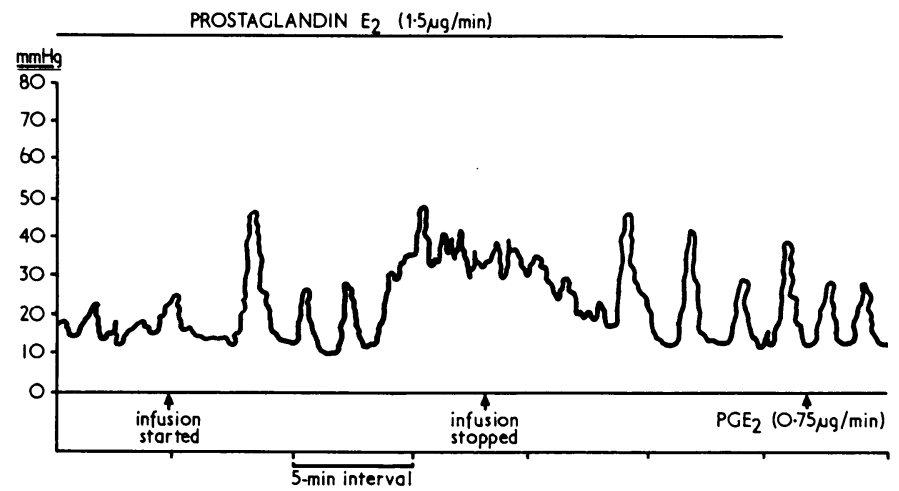

FIG. 2-Case 13. Hypertonus due to prostaglandin $\mathrm{E}_{2}(1.5 \mu \mathrm{g} / \mathrm{min})$.

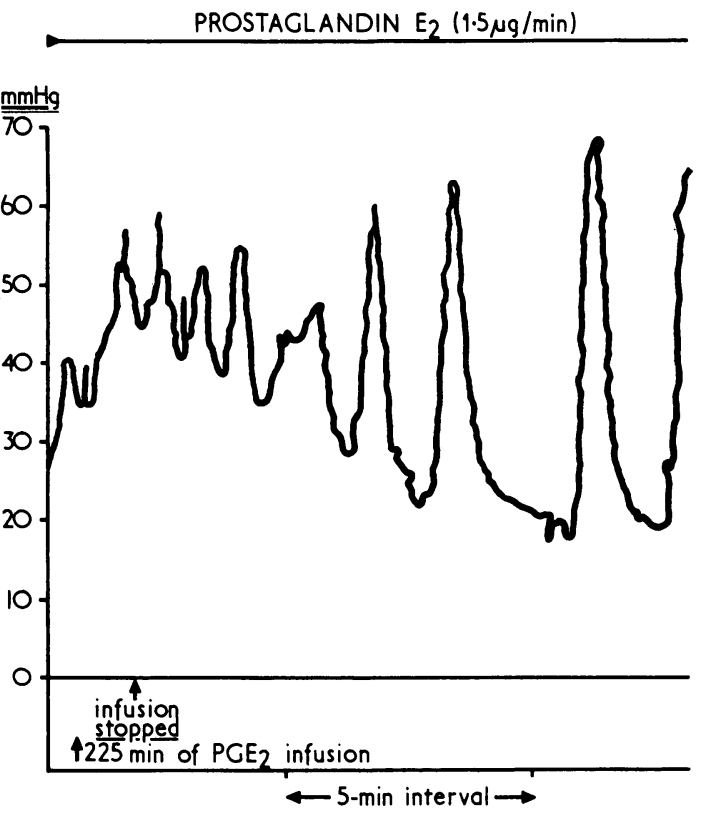

FIG. 3-Case 17. Hypertonus due to prostaglandin $\mathbf{E}_{2}$ $(1.5 \mu \mathrm{g} / \mathrm{min})$.

tonus occurred (pressure not falling below $40 \mathrm{~mm} \mathrm{Hg}$ ), lasting for six minutes. Normal uterine activity, with a resting tone of $15 \mathrm{~mm}$ $\mathrm{Hg}$, was restored within five minutes of cessation of the infusion. On this occasion the hypertonus was not detected clinically.

Case 20.-In this patient transient hypertonus $(30-40 \mathrm{~mm}$ $\mathrm{Hg}$ ) occurred 45 minutes after starting the infusion of prostaglandin $E_{2}(0.75 \mu \mathrm{g} / \mathrm{min})$. The effect disappeared spontaneously while the infusion continued.

In none of the last three cases was there any alteration detected in fetal heart rates, maternal pulse rate, or blood pressure during the raised uterine tone.

\section{Discussion}

The results of this study show that after amniotomy routine intravenous infusion of prostaglandins is at least as effective as routine intravenous oxytocin titration used in the same way for the induction of labour. In this series of 35 cases the average induction interval of nine hours (eight hours for Eprostaglandins) was only slightly longer than the 7 hours 42 minutes reported by Francis et al. (1970) using automatic oxytocin "titration" after amniotomy. The percentage of patients who had an unfavourable cervix, or who were of parity 3 or more, was much higher in the prostaglandin series, however, and both these factors are known to increase the risks of induction failure (Turnbull and Anderson, 1968). Induction with prostaglandins "failed" in only one case, but this was at least partly due to the supply being exhausted. These very satisfactory results confirm in general the work of Beazley et al. (1970), Embrey (1970), and Karim et al. (1970).

Nevertheless the fact that potentially dangerous uterine hypertonus developed in four patients receiving prostaglandin $\mathrm{E}_{2}$ indicates that these compounds can readily cause hyperstimulation of the uterus, with its attendant possibilities of reduced placental blood flow and fetal hypoxia (CaldeyroBarcia and Poseiro, 1958) and even of uterine rupture. While the uterine hypertonus was certainly due to too high a dose in one patient, a rise in the resting uterine tone developed unexpectedly in the other three patients, at a dosage level well within the range used in other centres in this country.

A reassuring feature, however, was that in each of these episodes of hypertonus, the resting uterine tone was restored to normal within five minutes of stopping the infusion. Embrey (1969) showed that the oxytocic effect of prostaglandins may persist for 30 to 60 minutes after stopping the infusion and that in some cases there may be no diminution in uterine activity. Fortunately, this does not seem to apply when hypertonus develops during prostaglandin administration.

The first reports of the use of prostaglandin $E_{1}$ and $E_{2}$ in human pregnancy (Bygdeman et al., 1968) suggested that unphysiological rise in uterine tone was of frequent occurrence and that these compounds were unsuitable for induction of labour. Karim et al. (1970) pointed out, however, that in none of Bygdeman's cases had resting uterine tone been increased above $14 \mathrm{~mm} \mathrm{Hg}$, and went on to induce labour successfully in 50 patients, using intravenous infusion of prostaglandin $E_{2}$ at a constant rate of $0.5 \mu \mathrm{g} / \mathrm{min}$. No evidence of hypertonus was reported, and though the induction-delivery interval was prolonged over 18 hours in six cases (12\%) amniotomy was not generally performed as a primary procedure. Beazley et al. (1970) varied the dose of prostaglandin $E_{\text {o }}$ to produce optimal uterine activity and noted one case in which transient hvpertonus occurred at an infusion rate of $40 \mathrm{ng} / \mathrm{kg} / \mathrm{min}$. Embrey (1970), in a similar study on 25 patients, noted no hypertonus with prostaglandin $\mathrm{E}_{2}$ in doses between 0.5 and $8 \mu \mathrm{g} / \mathrm{min}$.

Work in Cardiff started before publication of these most recent reports, and prostaglandin $\mathrm{E}_{\text {, was }}$ used first in a dose of $3 \mathrm{ug} / \mathrm{min}$, as being within the "threshold range" reported by Bygdeman et al. (1968) and Embrey (1969). Experience quickly showed that lower doses of prostaglandin $E_{2}$ should be used initially, and our practice now has been to begin with a dose of $0.75 \mu \mathrm{g} / \mathrm{min}$ and then double this, at intervals of two to four hours, if the uterine response is not satisfactory. The Table shows that it was necessary to double the dose once in only 7 out of 28 inductions with E prostaglandins. The results quoted by Karim et al. (1970) suggest that the starting dose should be even lower, $0.5 \mu \mathrm{g} / \mathrm{min}$.

Our results imply that the margin of safety between an effective dose and a dangerous overdose may be narrower with E prostaglandins than with oxytocin; furthermore, two of the episodes of hypertonus during prostaglandin $E_{2}$ infusion occurred entirely without warning. In the 130 cases in which Francis et al. (1970) induced labour by automatic titration of oxytocin in doses varying from 2 to $128 \mathrm{mU} / \mathrm{min}$ there was no episode of hypertonus. Clearly, more work is required to assess the optimum dosage of prostaglandin administration for the induction of labour and to compare it with oxytocin. At present synthetic oxytocin is readily available and inexpensive, but this may shortly be the case with prostaglandins now that their total synthesis has been achieved. Prostaglandins have the advantage that they do not cause antidiuresis, unlike oxytocin (Roberts et al., 1970), and they are also extremely effective within a much narrower dose range. On the other hand, a minor disadvantage of prostaglandin 
infusion has been the constant development of what appears to be an "inflammatory reaction" in the arm vein.

Studies in the clinical uses of prostaglandins are still at an early stage. Prostaglandin metabolites or derivatives may give even better results than the compounds available at present. A plea is made that in future a standard description of dose rate will be adopted- " $\mu \mathrm{g} / \mathrm{min}$ " seems simple and acceptable.

Rapid progress is being made, but the results reported here indicate that any future work on the uterus in late pregnancy must be very carefully monitored, by reliable measurement of amniotic fluid pressure, to detect any abnormal rise in uterine tone at the earliest possible moment.

We wish to thank Professor D. A. van Dorp, Vlaardingen, for the bulk of the supply of prostaglandins, and Dr. J. Pike, Upiohn Company. We also thank Mr. R. Marshall, Cardiff Royal Infirmary, for the illustrations, and the nursing staff of the department of obstetrics and gynaecology. Part of the work was carried out during the tenure of a United Cardiff Hospitals' Research Fellowship awarded to G.R.
References

Beazley, J. M., Dewhurst, C. J., and Gillespie, A. (1970). fournal of Obstetrics and Gynaecology of the British Commonwealth, 77, 193.

Bygdeman, M., Kwon, S. U., Mukherjee, T., and Wiqvist, N. (1968). American fournal of Obstetrics and Gynecology, 102, 317.

Caldeyro-Barcia, R., and Poseiro, J. J. (1958). International Congress of Gynaecology and Obstetrics, Montreal, p. 3.

Embrey, M. P. (1969). Fournal of Obstetrics and Gynaecology of the British Commonwealth, 76, 788 .

Embrey, M. P. (1970). British Medical fournal, 2, 256.

Embrey, M. P., and Anselmo, J. F. (1962). Fournal of Obstetrics and Gynaecology of the British Commonwealth, 69, 918 .

Embrey, M. P., and Morrison, D. L. (1968). Fournal of Obstetrics and Gynaecology of the British Commonwealth, 75, 829

Francis, J. G., Turnbull, A. C., and Thomas, F. F. (1970). Fournal of Obstetrics and Gynaecology of the British Commonwealth, 77, 594 .

Karim, S. M. M., Hillier, K., Trussell, R. R., Patel, R. C., and Tamusange, S. (1970). Fournal of Obstetrics and Gynaecology of the British Commonwealth, 77, 200 .

Pickles, V. R., Hall, W. J., Best, F. A., and Smith, G. N. (1965). Fournal of Obstetrics and Gynaecology of the British Commonwealth, 72, 185

Roberts, G., Anderson, A., McGarry, J., and Turnbull, A. C. (1970). British Medical fournal, $2,152$.

Turnbull, A. C., and Anderson, A. B. M. (1968). Fournal of Obstetrics and Gynaecology of the British Commonwealth, 75, 24.

\title{
Blood Clotting and Platelet Aggregation during Oral Progestogen Contraception: a Follow-up Study
}

\author{
L. POLLER, JEAN M. THOMSON, WENDY THOMAS, CAROL WRAY
}

British Medical fournal, 1971, 1, 705-707

\section{Summary}

A two-year follow-up study of progestogen-only contraception with chlormadinone acetate indicates no increase of the level of factors VII and X, as found after three cycles with all oestrogen-progestogen oral contraceptives. Clotting factors which were raised with combined preparations became normal after the sixth monthly cycle of progestogen and remained normal during the two-year period of study.

From 12 months onwards significant changes in the thromboelastograph pattern were recorded, but not to the same extent as with combined preparations. At two years platelet aggregation was significantly accelerated with chlormadinone acetate but was not as rapid as with combined preparations.

\section{Introduction}

Oral contraception with conventional oestrogen-progestogen combinations produces significant increases in blood-clotting factors (Thomson and Poller, 1965; Poller et al., 1968) and in the rate of platelet aggregation after three months (Poller et al., 1969a). These changes were not found in women after progestogen-only contraception with chlormadinone acetate. Increased rates of blood clotting and platelet aggregation from oestrogen-progestogen combinations rapidly returned to normal when this progestogen was substituted (Poller et al.,

\footnotetext{
Department of Haematology, Withington Hospital, University Hospital of South Manchester, Manchester M20 8LR

L. POLLER, M.D., M.C.PATH., Consultant Haematologist JEAN M. THOMSON, F.I.M.L.T., Chief Research Assistant WENDY THOMAS, A.I.M.L.T., Senior Technician CAROL WRAY, B.SC., Research Assistant
}

1969b). Coagulation and thromboelastograph studies have been described up to the three-month stage of chlormadinone acetate administration and platelet aggregation to the sixmonth stage, but it was stated that a long-term study must be performed to exclude a delayed or cumulative action. The present study is a follow-up in the same group of women, tested at regular intervals over the first two years of continuous chlormadinone acetate administration.

\section{Method of study}

Follow-up studies have been performed at intervals of three months up to 18 months and again at two years. Initially women were divided into two groups as previously: group 1, those who had changed from combined preparations; and group 2, those who had not previously received oral contraceptives. From the six-month stage results of the two groups were pooled as they were shown to be identical from the coagulation standpoint. The details of collection and technical procedures were as previously described (Poller et al., $1969 \mathrm{a}, 1969 \mathrm{~b})$, except that the platelet aggregation studies were set up within 15 minutes of venepuncture.

The following tests were performed at each visit: prothrombin time, cephalin time, and factors VII and $\mathrm{X}$ assays. Platelet aggregation (Chandler's tube technique) and a quantitative fibrinogen assay (Ratnoff and Menzie, 1951) were repeated at the two-year stage only. The progestogen group was compared throughout with parallel groups of normal women. Results of the tests were recorded in seconds and not as percentages.

Thromboelastograph patterns were recorded in women in group 2 only-that is, those not previously on oral contraceptives. The following values were measured: " $r$ " (reaction time), "k" (thrombin phase), and "ma" (maximum amplitude). Statistical analysis was performed on these values and the results were analysed on a time basis. 